\title{
Chemical Composition of Snow in Relation to Their Crystal Shapes
}

\author{
By Tsutomu Takahashi \\ Water Research Laboratory, Faculty of Science, Nagoya University \\ (Manuscript received 12 November 1963)
}

\begin{abstract}
Chemical composition of snow crystals has been investigated by the analysis of snow samples collected separately according to snow crystal shapes. The chemical elements analysed were $\mathrm{Cl}, \mathrm{Na}, \mathrm{NH}_{4}, \mathrm{SO}_{4}, \mathrm{Mg}, \mathrm{Ca}, \mathrm{NO}_{2}, \mathrm{Fe}$ and $\mathrm{Si}$. Snow crystals collected were classified into several groups; columns, rimed or not rimed dendrites, rimed radiating dendrites and graupels, etc. It has been found that the chemical composition shows marked dependence on the shape of snow crystals as follows;

(1) The concentrations of $\mathrm{Na}, \mathrm{Cl}$ and $\mathrm{NH}_{4}$ in columnar crystals were lowest among those in all shapes of crystals.

(2) The concentration of $\mathrm{NH}_{4}$ was highest in dendritic crystals.

(3) The concentrations of $\mathrm{Cl}$ and $\mathrm{Na}$ were highest in graupel. The relative concentration of the chemical elements of graupel was close to that of sea water.
\end{abstract}

\section{Introduction}

Chemical composition of rain water and snow has been investigated by many workers (Miyake 1939, Sugawara 1956, Junge and Werby 1958, Gorham 1958, Eriksson 1959), but our knowledge of chemical composition of snow in relation to shapes of snow crystal has not yet been obtained.

Investigation of chemical composition of snow crystals is considered to have an advantage over that of rain water for the elucidation of both the mechanism by which the chemical elements are captured in raindrops and snow crystals, and the mechanism of precipitation in cloud, because the form and the size of a snow crystal provide much information on the history of its growth including temperature, humidity, abundance of supercooled droplets in a cloud, in which it has grown. (Nakaya and Terada 1935, Nakaya 1951)

The present paper shows the chemical composition of snow which was collected separately according to the shape of snow crystals. The snow samples were collected at Kitamoshiri, which is in the northern part of Hokkaido, $600 \mathrm{~m}$ high above the sea level and far from industrial areas (Fig. 1).

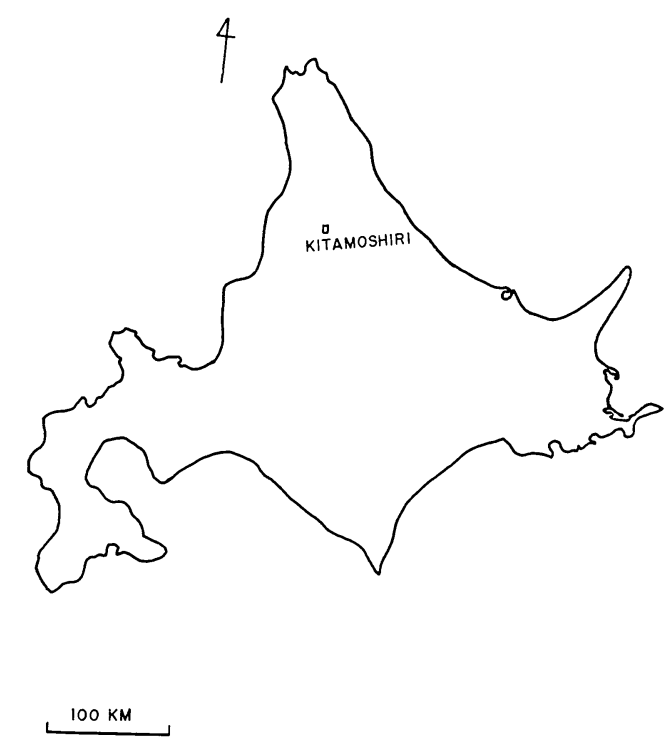

Fig. 1. Observation site, Kitamoshiri, Hokkaido.

\section{Methods of observation and measurement}

Observation and sampling of snow crystals during snowfall were carried out at Kitamoshiri, 10th through 20th, January, 1963.

Procedures :

(1) Sampling of snow crystals.

(2) Preparation of plastic replicas of snow crystals. 
To collect snow, a vinyl-sheet $(2 \mathrm{~m} \times 2 \mathrm{~m})$ was spread on the surface of ground snow (Photo. $1)$. When an appropriate amount of snow had been collected or when a shape of crystals falling was observed to change, snow on the sheet was inserted into a vinyl-sack and kept in an Igloo. After a time, the snow in the sack was put into a large glass beaker which was warmed with hot water. After the snow had been melted in the beaker, thus obtained water was poured into a polyethylene bottle and was frozen again. About one hundred of such snow samples were carried to the laboratory and chemical analyses were made with them.

While the sampling of snow crystals was made, replicas of snow crystals were prepared by the use of formar solution every 10 or 15 minutes to fix the shape and size of snow crystals. The methods of chemical analyses employed were as follows;

$\mathrm{Cl}$ Colorimetric Mercuric-Thiocyanate

$\mathrm{Na}$ Flame photometric

$\mathrm{NH}_{4}$ Colorimetric Alkaline phenol, and

hypochlorite solution

$\mathrm{SO}_{4}$ Colorimetric Barium chromate Nephelometric Barium chloride

$\mathrm{Mg}$ Titration $\mathrm{Mg}$-EDTA, EBT

$\mathrm{Ca}$ Titration KOH, 2-Hydroxy-1(2-hydroxy-4-sulfo-1naphthylazo)-3-naphthoic Acid

$\mathrm{NO}_{2}$ Colorimetric 1-Amino-2-naphthol-4sulfonic Acid

$\mathrm{Fe}$ Colorimetric Thiocyanate

$\mathrm{Si}$ Colorimetric Ammonium Molybdate

\section{Results}

\subsection{Columns}

The result obtained on 13th, January, 1963 is shown in Fig. 2. Cloud form and temperatures of cloud top and cloud base obtained from radiosonde observation of Wakkanai Weather Station are shown in the upper part of this figure. The shapes and the sizes of snow crystals and the concentrations of $\mathrm{Cl}$, $\mathrm{Na}, \mathrm{SO}_{4}, \mathrm{NH}_{4}, \mathrm{Mg}, \mathrm{NO}_{2}$ and $\mathrm{Fe}$ in the snow crystals which were collected at each time, are also shown in the figure. In the bottom of the figure, the intensity of precipitation is shown.

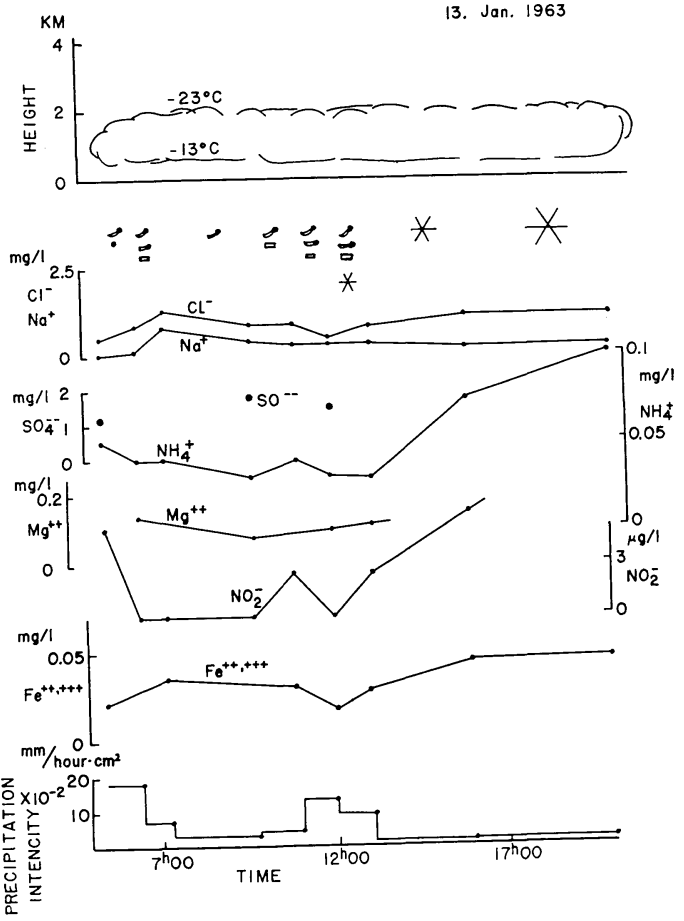

Fig. 2. Time variation of concentration in columnar crystal and dendrites.

Graphic symbols and their photographs of snow shapes are given in Table 1 and in Photos. 2,3, 4 and 5 respectively. As is seen

Table 1. Graphic symbol of snow crystal.

$\begin{array}{ll}- & \begin{array}{l}\text { Irregular-rimed particles } \\ \text { Irregular snow crystals } \\ \text { with rimed particls }\end{array} \\ \square & \text { Columns } \\ * & \text { Plates } \\ * & \text { Dendrites } \\ \triangle & \text { Radiating dendrites } \\ * & \text { Dendrites and } \\ * & \text { Rimed-Dendrites } \\ * & \text { Rimed Radiating dendrites }\end{array}$

in the figure, the concentrations of $\mathrm{Cl}, \mathrm{Na}$ and $\mathrm{NH}_{4}$ in columnar crystals were low. With decreasing proportion of columnar crystals to dendritic crystals in snowfall, concentrations of $\mathrm{Cl}, \mathrm{Na}$ and $\mathrm{NH}_{4}$ increased. 


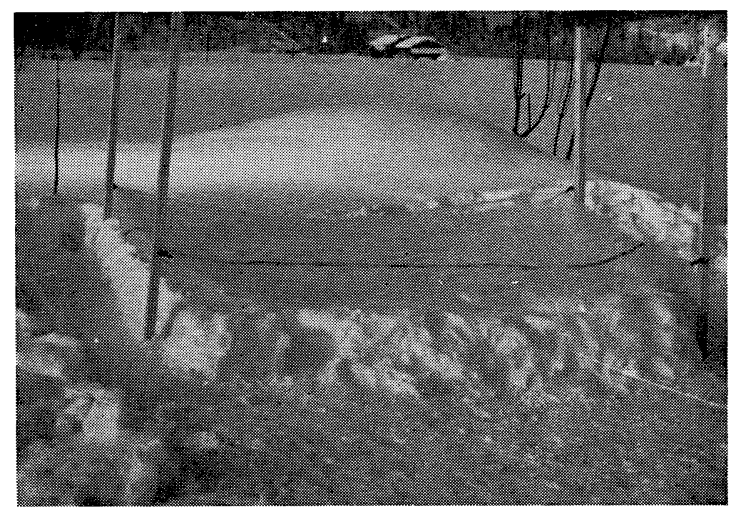

Photo. 1. Vinyl sheet spread on the ground snow.

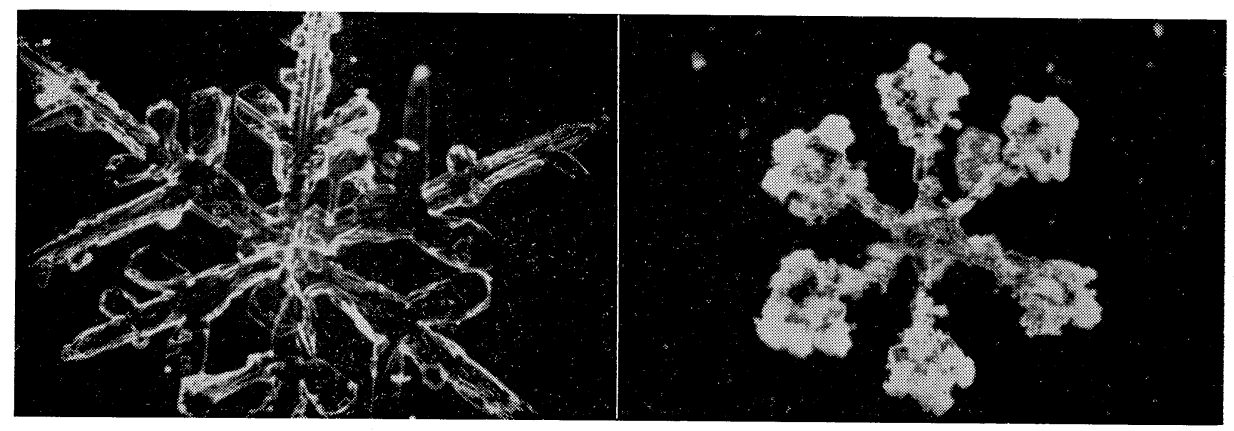

Photo. 2. Dendrite.

Photo. 3. Rimed Dendrite.

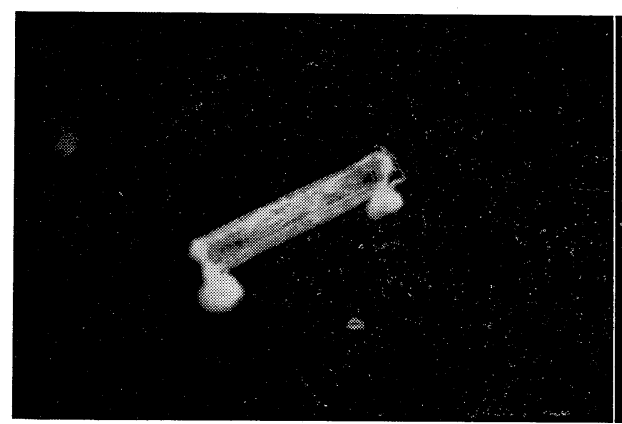

Photo. 4. Column-partly rimed.

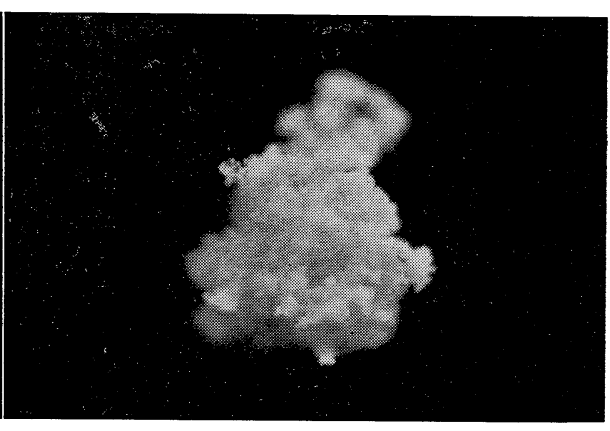

Photo. 5. Graupel. 


\section{2 Dendrites}

Variation of the concentration of chemical elements in rimed dendritic snow crystals and not-rimed dendritic snow crystals in a snowfall is shown in Fig. 3. The concentrations of $\mathrm{Cl}$, $\mathrm{Na}$ and $\mathrm{NH}_{4}$ in dendritic snow crystals were high. When rimed dendritic snow crystals
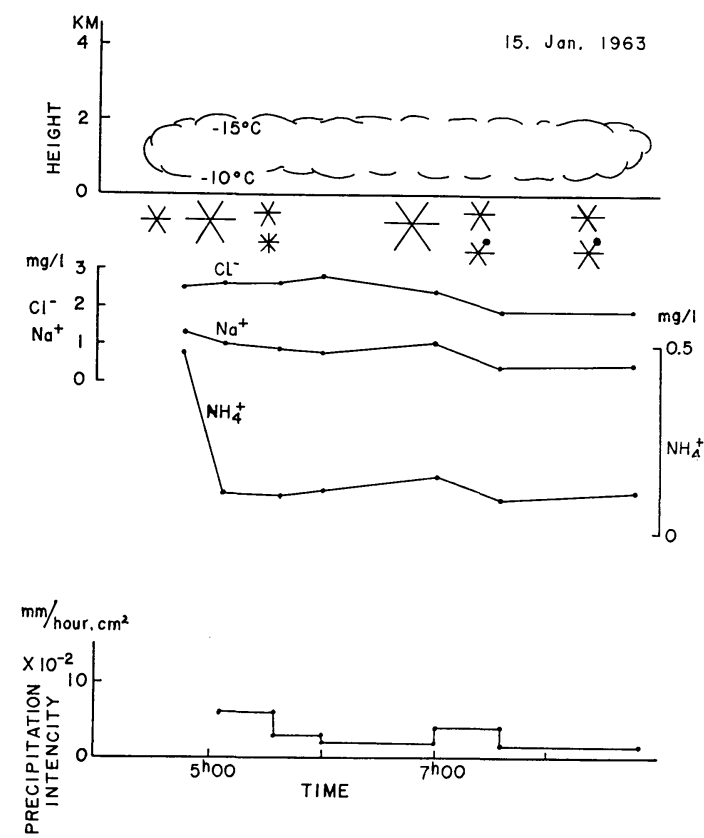

Fig. 3. Time variation of concentration in dendritic crystal.

appeared, the concentration of $\mathrm{Cl}, \mathrm{Na}$ and $\mathrm{NH}_{4}$ became low.

\subsection{Graupel}

Fig. 4 shows time variation of the chemical

Table 2. Time variation of concentration in graupel and others.

\begin{tabular}{|c|c|c|c|c|c|c|c|c|c|}
\hline & $\mathrm{Cl}^{-}$ & $\mathrm{Na}^{+}$ & $\mathrm{NH}_{4}^{+}$ & $\mathrm{SO}_{4}^{--}$ & $\mathrm{Mg}^{++}$ & $\mathrm{Ca}^{++}$ & $\mathrm{NO}_{2}^{-}$ & $\mathrm{Fe}^{+++,+++}$ & $\mathrm{Si}$ \\
\hline$\square \square \Omega$ & 1.1 & 0.42 & 0.05 & (1.6) & 0.15 & 0.037 & 0.0008 & 0.026 & $(0.018)$ \\
\hline$x$ & 4.1 & 1.5 & 0.27 & (4.4) & $(0.34)$ & $(0.27)$ & $(0.001)$ & 0.042 & (0.043) \\
\hline$x *$ & 2.3 & 0.68 & 0.25 & - & $(0.08)$ & $(0.07)$ & $(0.006)$ & 0.045 & - \\
\hline * & 2.1 & 1.0 & 0.03 & 0.61 & 0.11 & 0.015 & 0.001 & 0.04 & 0.014 \\
\hline 朴 $\triangle$ & 4.3 & 1.9 & 0.03 & 1.3 & 0.28 & 0.045 & 0.001 & 0.03 & 0.011 \\
\hline $\begin{array}{l}\text { Total } \\
\text { Average }\end{array}$ & 2.1 & 0.82 & 0.06 & 1.1 & 0.16 & 0.035 & 0.002 & 0.035 & 0.014 \\
\hline
\end{tabular}

$\mathrm{MG} / \mathrm{L}$
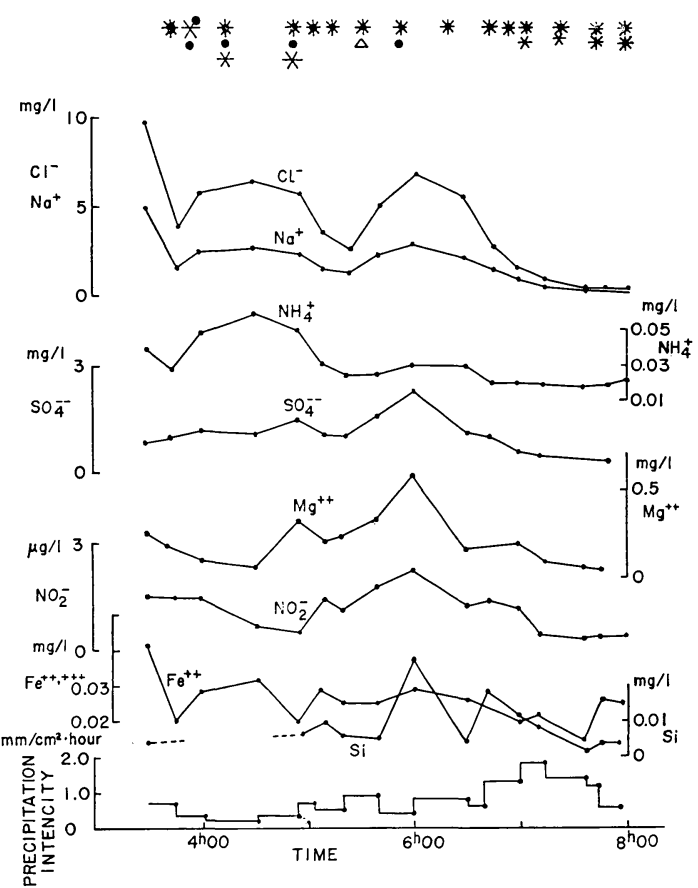

Fig. 4. Time variation of concentration in graupel and others.

elements in graupel. The concentrations of $\mathrm{Cl}, \mathrm{Na}$ and $\mathrm{NH}_{4}$ decreased with time. When dendritic snow crystals appeared, concentrations of $\mathrm{Cl}, \mathrm{Na}$ and $\mathrm{NH}_{4}$ became high. When dendritic snow crystals disappeared, the concentration of the elements decreased. When graupel began to fall, the concentrations of $\mathrm{Na}, \mathrm{Cl}, \mathrm{Mg}, \mathrm{NO}_{2}$ and $\mathrm{Si}$ increased abruptly, but concentration of $\mathrm{NH}_{4}$ did not change. When rimed radiating dendritic crystals fell, concentrations of $\mathrm{Cl}$, $\mathrm{Na}$ and $\mathrm{NH}_{4}$ became low.

\section{Discussion}

Average concentrations of chemical elements in each typical shape of snow crystals are shown in Table 2 (The samples of snow obtained when snow crystals of more than two kinds of crystal shapes fell simultaneously, were omitted.). These values are an average concentration of total precipitation of each crystal shape.

The concentrations of $\mathrm{Cl}, \mathrm{Na}$ and 
$\mathrm{NH}_{4}$ in snow of columnar shape were 1.1 $\mathrm{mg} l^{-1}, 0.42 \mathrm{mg}^{-1}$ and $0.05 \mathrm{mg} l^{-1}$ respective1y. The concentrations of $\mathrm{Cl}, \mathrm{Na}$ and $\mathrm{NH}_{4}$ in snow of dendritic shape were $4.1 \mathrm{mg} \mathrm{l}^{-1}, 1.5$ $\mathrm{mg} l^{-1}$ and $0.27 \mathrm{mg}^{-1}$ respectively. The concentrations of $\mathrm{Cl}, \mathrm{Na}$, and $\mathrm{NH}_{4}$ in graupel shape were $4.3 \mathrm{mg} l^{-1}, 1.9 \mathrm{mg} l^{-1}, 0.03 \mathrm{mg} l^{-1}$ respectively. The values in parentheses can not be considered as representative, because the number of samples for each of time was small.

In order to consider the origins of chemical substances in snow crystals, chemical composition of snow was compared with that of the sea water and with that of aerosols of continental or industrial origin.

The ratios of the concentration of $\mathrm{Na}$ to $\mathrm{Cl}, \mathrm{Na}$ to $\mathrm{Mg}, \mathrm{Na}$ to $\mathrm{SO}_{4}$ are shown in Fig. $5,6,7$, respectively (The symbol $\boldsymbol{\Delta}$ means

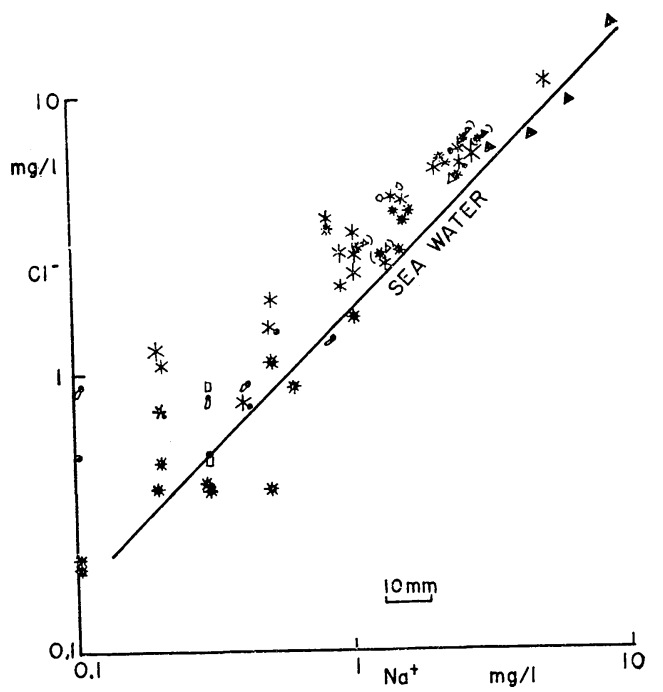

Fig. 5. The ratio of the concentration of $\mathrm{Na}$ and $\mathrm{Cl}$.

the graupel which was collected in Hokuriku district, Honshu.). The ratios between these chemical elements in graupel were close to the ratios in sea water, but the ratios in dendritic crystals were far from that in sea water. The ratio between $\mathrm{NH}_{4}$ and $\mathrm{SO}_{4}$ in snow crystals is shown in Fig. 8. Dendritic snow crystals contained larger amount of $\mathrm{NH}_{4}$ than the graupel. The ratio $\mathrm{NH}_{4} / \mathrm{SO}_{4}$ in snow and graupel was very different from that of $\left(\mathrm{NH}_{4}\right)_{2} \mathrm{SO}_{4}$, as can be seen from the figure.

From a consideration of geochemical aspects of these substances, $\mathrm{Na}$ may be taken for

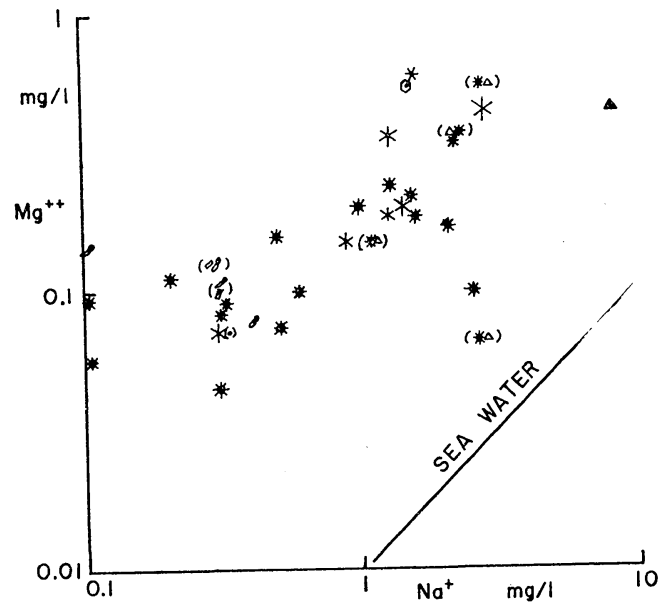

Fig. 6. The ratio of the concentration of $\mathrm{Na}$ and $\mathrm{Mg}$.

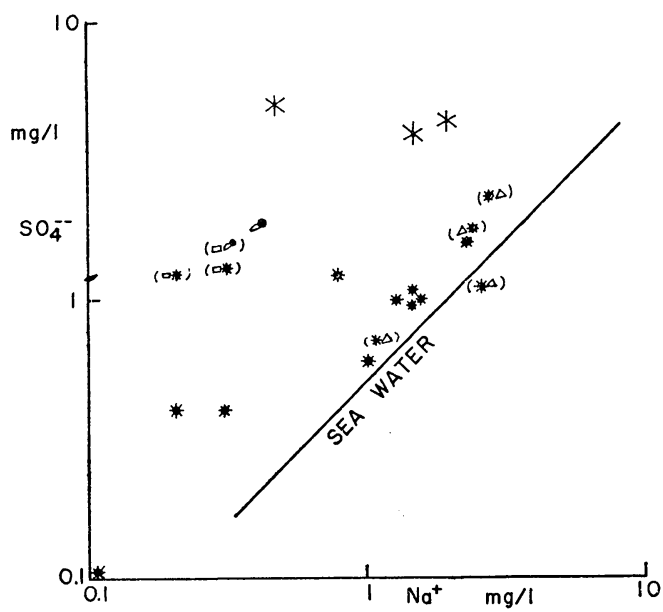

Fig. 7. The ratio of the concentration of $\mathrm{Na}$ and $\mathrm{SO}_{4}$.

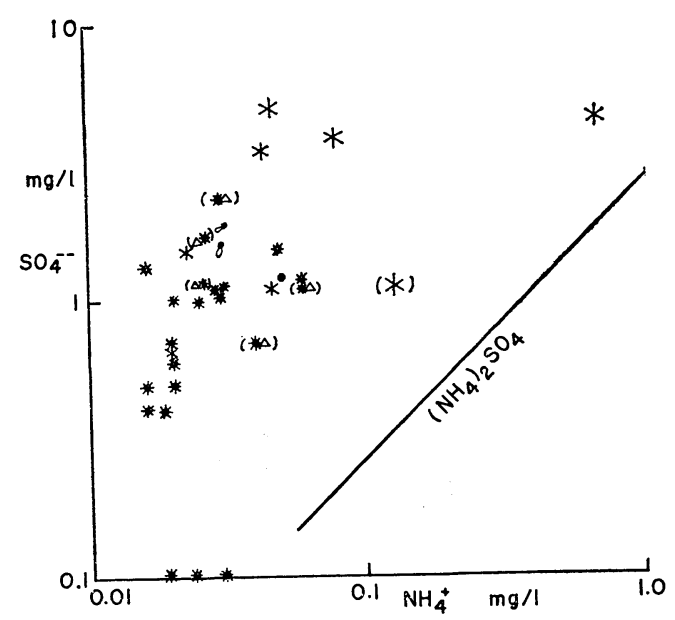

Fig. 8. The ratio of the concentration of $\mathrm{NH}_{4}$ and $\mathrm{SO}_{4}$. 


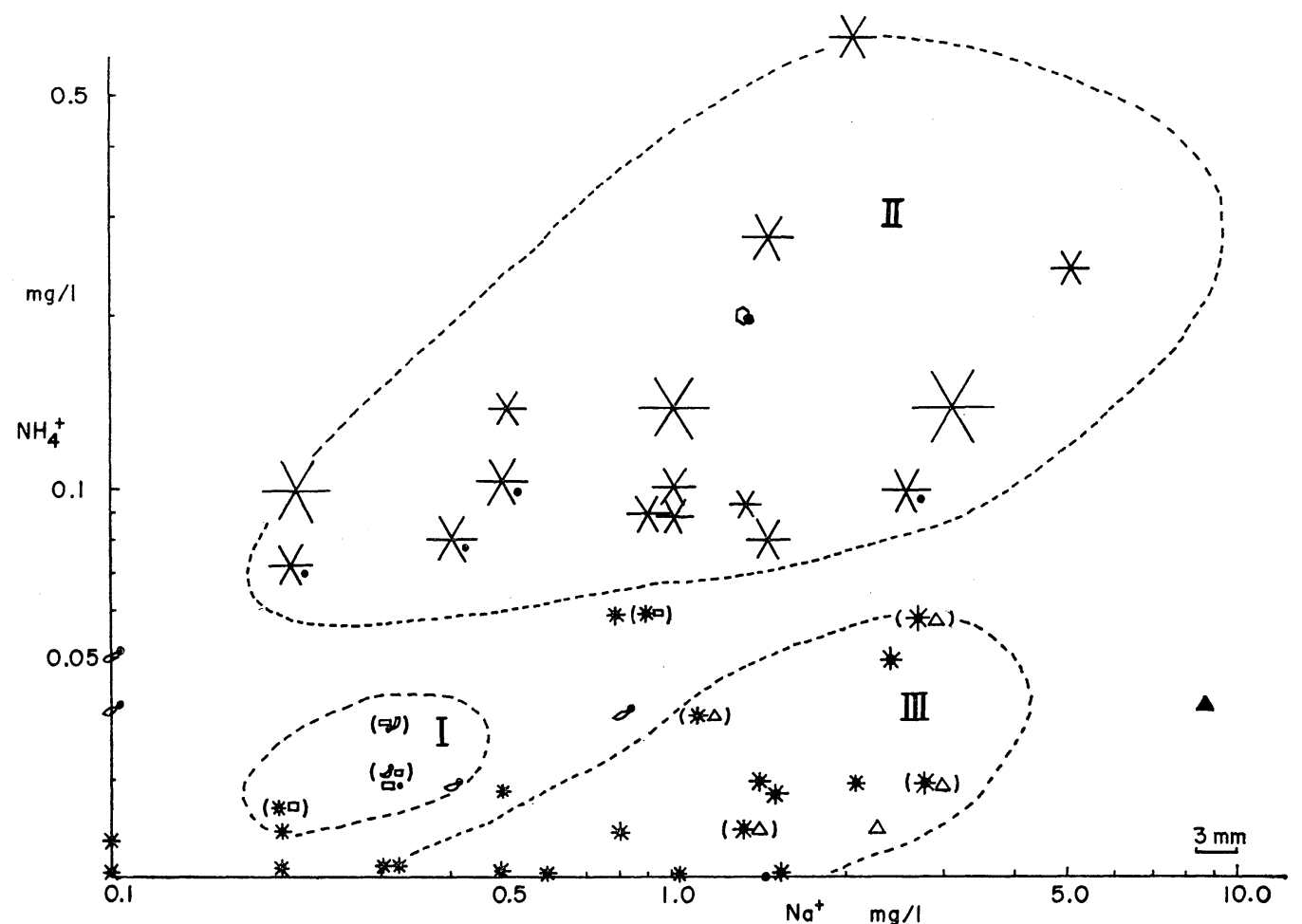

Fig. 9. The ratio of the concentration of $\mathrm{Na}$ and $\mathrm{NH}_{4}$ for each shape of crystals.

I. columnar crystal

II. dendritic crystal

III. graupel and radiating dendritic crystal

the representative chemical elements of sea origin, and $\mathrm{NH}_{4}$ may be taken for that of industrial at least in Hokkaido. The relation between them is shown in Fig. 9.

In regards to the concentration of $\mathrm{Na}$ and $\mathrm{NH}_{4}$, snow crystals were divided into three groups. The first of them is the group of the columnar snow crystals (I). The concentrations of $\mathrm{Na}$ and $\mathrm{NH}_{4}$ in this group of snow were both less than those in the other shapes of snow crystal.

The second group (II) is that of dendritic snow crystals ; the concentration of $\mathrm{NH}_{4}$ was highest and also the concentration of $\mathrm{Na}$ was relatively high. The ratio of chemical elements, $\mathrm{NH}_{4} / \mathrm{Na}$, was highest.

The third group (III) is that of graupel and rimed radiating dendritic crystals. In this case the ratio $\mathrm{Na} / \mathrm{NH}_{4}$ was highest of three groups. The concentration of $\mathrm{Na}$ was highest in graupel. Although chemical elements found in snow is considered to have been included in snow by complicated processes, it may be reasonable to consider the following processes:

(1) chemical elements included in ice nuclei on which snow crystal was formed.

(2) chemical elements included in condensation nuclei of water droplets which were adhered to snow crystal especially in the case of rimed crystals.

(3) chemical elements in aerosols captured by snow crystal during its growth in clouds.

(4) chemical elements in aerosols captured by a snow crystal after its leaving from cloud base (a) by Brownian motion of aerosol particles to snow crystal or (b) by the gravitational accretion process.

In order to know which process was important, some considerations are made. The facts that chemical concentration in columnar crystal was less than in the other shapes of snow crystals and that the cloud base from which columnar crystals fell was very near to the ground, show that the process (1) may be discarded so far as the chemical elements 
discussed in the present paper are concerned, because the ice nuclei in the atmosphere over Japan have been found to be mainly particles of minerals, and loess (Kumai 1961, Isono 1955) in the concentration to be considered. Loess include $\mathrm{Na}$ element only about $1 \%$ to total chemical elements (Miyake and others 1956). Columnar crystal whose length is $1 \mathrm{~mm}$, is $0.005 \mathrm{mg}$ according to Nakaya. If this columnar crystal is formed on loess particle of diameter $2 \mu$, the concentration of $\mathrm{Na}$ in columnar crystal is below $0.1 \mathrm{mg} l^{-1}$. The concentration of $\mathrm{Si}$ in snow crystals which is considered to be due to clay minerals or loess was $0.02 \mathrm{mg} \mathrm{l}^{-1}$. This fact also shows that $\mathrm{Na}$ which is due to clay minerals or loess must be below $0.002 \mathrm{mg} \mathrm{l}^{-1}$. As the concentration of chemical element in irregular rimed particles and rimed columnar crystal was low, cloud droplets on such crystals must have been formed on small condensation nuclei which do not include large amount of soluble $\mathrm{Na}$ and $\mathrm{NH}_{4}$. The amount of chemical elements obtained in cloud must have been small, because the concentration of aerosol

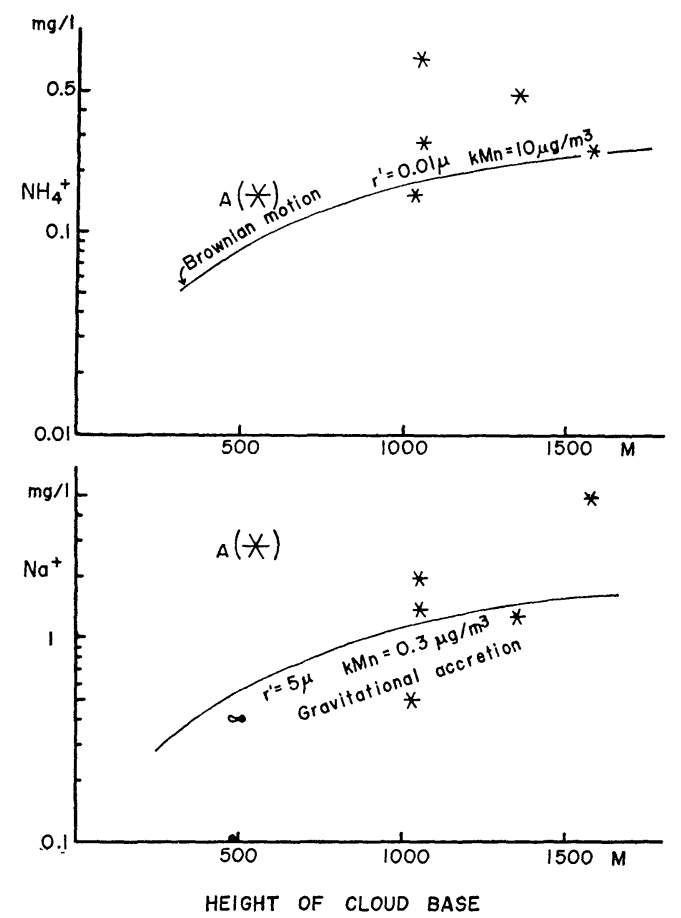

Fig. 10. Upper : Concentration of $\mathrm{NH}_{4}$ against the height of cloud base.

Lower: Concentration of $\mathrm{Na}$ against the height of cloud base. particles in cloud must be low. Therefore, the fact that the concentration in dendritic crystal is higher than columnar crystal may result from the longer distance from cloud base to ground in dendritic crystal. If most amount of chemical elements of dendritic snow crystals is captured below cloud base, the chemical concentration in dendritic snow crystals must have some relation with the height of cloud base above the ground. Fig. 10 is a plot of the concentration of $\mathrm{NH}_{4}$ and $\mathrm{Na}$ in dendritic and columnar crystal obtained at first stage of snow fall against the height of the cloud base above the ground. According to Nakaya's diagram, dendritic crystals grow at temperatures between $-14^{\circ} \mathrm{C}$ and $-17^{\circ} \mathrm{C}$ and columnar crystals grow between $-9^{\circ} \mathrm{C}$ and $-14^{\circ} \mathrm{C}$ or between $-17^{\circ} \mathrm{C}$ and $-21^{\circ} \mathrm{C}$ under the condition whose relative humidity over ice is $110 \%$. As it is difficult to determine the height of the cloud base from 12-hour radiosonde's data, the height of cloud base is assumed to be the height at which snow crystal ceased to grow. It is tentatively assumed that grown up dendritic crystals fall out of the cloud base at $-14^{\circ} \mathrm{C}$ and grown up columnar crystals fall out of the cloud base at $-9^{\circ} \mathrm{C}$. During the fall no growth and no evaporation are assumed to occur. The height of these temperature levels are determined from radiosonde's data and the surface data at the site. The fall speed of dendrite is assumed to be $30 \mathrm{~cm} \mathrm{sec}^{-1}$ by Nakaya and Terada.

The relation between concentration and the height of cloud base is shown at the upper part of Fig. 10. When the height of cloud base increases from $500 \mathrm{~m}$ to $1000 \mathrm{~m}$, the concentration of $\mathrm{NH}_{4}$ increases with the height of cloud base. Sample (A) was collected at the beginning of a snowfall after absence of snowfall longer than a day, so that the concentration of aerosol particles in air in this case was likely to be higher as compared with that in other samples.

As for $\mathrm{Na}$, the relation between its concentration in snow and the height of cloud base is shown in the lower part of Fig. 10. The concentration of $\mathrm{Na}$ increases with the height of cloud base except the sample (A). This fact shows that the aerosol particles containing $\mathrm{Na}$ reach at least the level $1500 \mathrm{~m}$ above the ground. In order to explain above 
results, two mechanisms are considered. One of these is that due to the Brownian motion of aerosol particles to snow crystals and the other is that due to washing out of aerosol particles by the gravitational accretion process.

At first, the rate of capture of aerosol by Brownian motion is calculated, assuming the form of the dendritic crystal as a disk of radius $r$ in order to simplify the following calculation. The electrostatic capacity of this disk is denoted by $c$, a mass of this disk by $m$, the radius of aerosol particles by $r^{\prime}$ and the number of the aerosol particles per unit volume in the air by $n$. The total number of aerosol particles which is captured to the snow crystal by the process of Brownian motion $\left(n^{\prime}\right)$ is

$$
\frac{d n^{\prime}}{d t}=4 \pi c D n
$$

, where $D$ is the diffusion constant of the aerosols in the air due to Brownian motion. In the case of a disk, this equation becomes

$$
\frac{d n^{\prime}}{d t}=4 \pi \frac{2 r}{\pi} \frac{R T\left(1+A L / r^{\prime}\right)}{6 \pi \eta r^{\prime} N} n
$$

, where $\eta$ is viscosity of the air, $R$ is the gas constant, $L$ is the mean free path of air molecules, $N$ is the Loschmidt's number, and $A$ is a constant. If we put $r=0.1 \mathrm{~cm}$, the mass $m$ of that snow crystal is $0.02 \mathrm{mg}$ according to Nakaya and Terada (1935). The mass of an aerosol particle is denoted by $M$, and the concentration of $\mathrm{NH}_{4}$ or $\mathrm{Na}$ in it by $k$. The concentration $(K)$ of aerosol particles in the snow crystal at 1000 seconds after the beginning of attachment is given by

$$
\begin{aligned}
K_{1000 \mathrm{sec}} & =\frac{k M}{m} \int_{0}^{1000} \frac{d n^{\prime}}{d t} d t \\
& =5 \cdot 10^{-4} \frac{1+8 \cdot 10^{-6} / r^{\prime}}{r^{\prime}} n k M
\end{aligned}
$$

The concentration of aerosol calculated by this equation is given in Table 3 .

Table 3. The concentration of aerosol particles in a snow crystal calculated.

\begin{tabular}{rlll}
\hline$r^{\prime}=1 \mu$ & $0.1 \mu$ & $0.01 \mu$ \\
\hline
\end{tabular}

$K(1000 \mathrm{sec}) \quad 5 \cdot 10^{-4} \mathrm{mg} l^{-1} 10^{-3} \mathrm{mg} l^{-1} 0.05 \mathrm{mg} l^{-1}$

As for washing out of the aerosol particles by the gravitational accretion process, the concentration aerosol in a snow crystal $(K)$ is given by

$$
K=k^{\prime} \frac{k n M L^{\prime} \pi r^{2}}{m}
$$

, where $L^{\prime}$ is the height of cloud base and $K^{\prime}$ is the collection efficiency. The collection efficiency is calculated by Langmuir's diagram. It is assumed that the collection efficiency concerning snow crystal can apply to the calculation concerning ribbon. As for the case when diameter of snow crystal is replaced by the width of ribbon, the collection efficiency $\left(R^{\prime}\right)$ of aerosol particle whose radius is $5 \mu$ becomes 0.05 . When the aerosol particle is assumed to be captured to the branch of snow crystal, the collection efficiency of aerosol particle whose radius is $1.2 \mu$, becomes 0.05 , assuming the width of branch of snow crystal is one tenth of the diameter of this crystal. The concentration of sea salt nuclei is referred to the observation of Woodcock (1953). As observation site, Kitamoshiri is only $20 \mathrm{~km}$ far from sea coast, the observation of Woodcock of the height $1000 \mathrm{~m}$ over sea is assumed to be able to use in Hokkaido. The concentration of sea salt nuclei whose radius is greater than $5 \mu$, is $0.3 \mu \mathrm{g} \mathrm{m}^{-3}$ and that is greater than $1.2 \mu$, is $1.6 \mu \mathrm{g} \mathrm{m}^{-3}$. When the concentration of $\mathrm{Na}$ in giant sea salt nuclei is assumed to be 0.5 , the concentration of aerosol particles captured in a snow crystal while it fell from the cloud base $1000 \mathrm{~m}$ above the ground, is given in Table 4, where it is assumed that the size of sea salt nuclei is uniformly $5 \mu$ or $1.2 \mu$, and their concentration is $0.3 \mu \mathrm{g} \mathrm{m}^{-3}$ or $1.6 \mu \mathrm{g} \mathrm{m}^{-3}$ respectively. Surface area is assumed to be the same in both considerations.

Table 4. The concentration of aerosol particles in a snow crystal captured by gravitational accretion process.

$K_{1000 \mathrm{~m}} \begin{aligned} & \text { As the ribbon } \\ & \text { whose width is width is } 0.2 \mathrm{~mm} \\ & 2 \mathrm{~mm}\end{aligned}$
$1.1 \mathrm{mg} \mathrm{l}^{-1}$

Though the chemical composition of containing $\mathrm{NH}_{4}$ does not seem to be $\left(\mathrm{NH}_{4}\right)_{2} \mathrm{SO}_{4}$ as suggested by Junge (1953), the size of aerosol 
particles containing $\mathrm{NH}_{4}$ must be below radius $1 \mu$. As the size of radius smaller than $1 \mu$ can not be captured in snow crystal by the gravitational accretion process, $\mathrm{NH}_{4}$ is captured in crystal by Brownian motion. The calculated values in which the radius of aerosol particle is assumed to $0.01 \mu$, are plotted in the upper part in Fig. 10. The order of observed value can be explained. Therefore, $\mathrm{NH}_{4}$ might be captured by the snow crystal by Brownian motion from the cloud base to the ground. A line which is denoted at the lower part of Fig. 10, shows the calculated value in which aerosol particle is captured by the gravitational accretion process. The calculated value may also explain the order of observed value. This concentration becomes higher if the aerosol particle is captured to the branch of snow crystal. If aerosol particle was captured by the Brownian motion, $r^{\prime}=0.01 \mu, n=1000$ $\mu \mathrm{gm}^{-3}$ must be assumed in order to explain the observed value. Therefore, it might be said that $\mathrm{Na}$ in dendritic crystal is captured by the gravitational accretion process from the cloud base to the ground.

Third group (III) is that of graupel and rimed radiating dendritic crystals. The characteristic nature of this group is highest concentration of $\mathrm{Na}$ and low concentration of $\mathrm{NH}_{4}$. The high concentration of $\mathrm{Na}$ in graupel may be explained as follows. Graupel has been found to consist of many large frozen droplets from microscopic study of thin section of graupel (Magono and the author 1961). From the fact that the chemical composition of graupel was close to that of sea water, it is considered that large frozen droplets included in graupel were formed initially on giant sea salt nuclei. Low concentration of $\mathrm{NH}_{4}$ in graupel may be explained as follows; falling speed of graupel is $2 \mathrm{~m} \mathrm{sec}^{-1}$ by Nakaya and Terada, which is seven times of the falling speed of dendritic crystal, so that elapsed time from cloud base to the ground becomes one-seventh of that of dendritic crystal, assuming height of cloud base is the same in both crystal shapes. If $\mathrm{NH}_{4}$ is captured by Brownian motion, graupel may capture only one-seventh of $\mathrm{NH}_{4}$ as compared with the value of dendritic crystal. The reason why rimed radiating dendritic crystal has less concentration of
$\mathrm{NH}_{4}$ than the other groups, may be explained as the same as the case of graupel. The value of the concentration of $\mathrm{Na}$ in rimed radiating dendritic crystal varied with samples. These variations may be explained as follows; even if the amount of $\mathrm{Na}$ captured below clound base in graupel and rimed radiating dendritic crystal, is the same of dendritic crystal, the concentration in the former must be lower than the latter, because the mass of graupel, rimed radiating dendritic crystal and dendritic crystal of each same diameter $2 \mathrm{~mm}$, is $0.4 \mathrm{mg}, 0.1 \mathrm{mg}$ and $0.02 \mathrm{mg}$ respectively. The concentration becomes one 20th and one 5 th compared with dendritic crystal. Therefore, the concentration of $\mathrm{Na}$ in graupel and radiating dendritic crystal may not be settled below cloud but in the cloud. The high concentration of $\mathrm{Na}$ in some rimed radiating dendritic crystal must be due to the capturing of cloud droplets formed on giant nuclei in cloud.

\section{Conclusion}

Chemical elements have been analysed for each shape of snow crystals. Results obtained are as follows:

(a) The concentrations of chemical elements differed in each shape of snow crystals systematically, that is, columnar crystal, dendritic crystal and graupel had different chemical compositions respectively.

(b) The concentration of $\mathrm{Na}, \mathrm{Cl}$ and $\mathrm{NH}_{4}$ in columnar crystals was lowest among other shapes. The low concentration may be due to the shorter path from cloud base to the ground.

(c) The concentration of $\mathrm{NH}_{4}$ was greatest in the dendritic crystals. The ratio of chemical elements, $\mathrm{NH}_{4}$ to $\mathrm{Na}$ in dendritic snow crystal was largest among that ratio in all shapes. $\mathrm{Na}$ and $\mathrm{NH}_{4}$ in dendritic crystal are considered to have been captured mainly during the fall from cloud base to the ground.

(d) The concentrations of $\mathrm{Cl}$ and $\mathrm{Na}$ were greatest in graupel. The ratio of $\mathrm{Na}$ to $\mathrm{NH}_{4}$ is largest in graupel and rimed radiating dendritic crystal. The relative composition of the chemical elements of graupel was close to that of the sea water. This may be due to

Vol. 41, No. 6, 1963 
the large frozen droplets formed on giant sea salt nuclei which were present in graupel body.

To clarify the present problem more definitely, simultaneous measurements of chemical elements of snow crystal and aerosol particles in the air is considered to be urgently needed.

\section{Acknowledgement}

The author wishes to express his best thanks to Prof. K. Isono and Dr. M. Komabayasi for their useful suggestions. The author is deeply indebted to Prof. Y. Kitano, Prof. Y. Saijo, Dr. N. Kanamori and Dr. N. Handa for their kind instructions for the procedure of chemical analyses. His great thanks is to Prof. S. Sasao, Hokkaido University who offered many facilities for the observation in Kitamoshiri area.

This work is a part of "Studies of cloud physics and mechanisms of rainfall over the Pacific and isolated island."

\section{References}

Eriksson, E. (1959): The yearly circulation of chloride and sulfur in nature; meteorological. geochemical and pedological implications, Part 1. Tellus, 11, 375-403.

Gorham, E. (1958): The influence and importance of daily weather conditions in the supply of chloride, sulphate and other ions to fresh waters from atmospheric precipitation. Proc. Roy. Soc., B, 241, 147-178.
Isono, K. (1955): On ice-crystal nuclei and other substances found in snow crystals. J. Met., 12, 456-461.

Junge, C. E. and R. T. Werby (1958): The concentration of chloride, sodium, potassium, calcium, and sulfate in rain water over the United States. J. Met., 15, 417-425.

Junge, C. (1953): Rolle der Aerosole und der gasförmigen Beimengungen der Luft im Spurenstoffhaushalt der Troposphäre. Tellus, 5, 1-26.

Kumai, M. (1961): Snow crystals and the identification of the nuclei in the northern United States of America. J. Met., 18, 139-150.

Langmuir, I. (1944): Mathematical investigation of water droplet trajectories. U. S. Air Army Forces Tech. Rep., No. RL-224.

Miyake, Y. (1939): The chemistry of rainwater. (in Japanese) J. Met. Soc. Japan, Ser, II, 17, 20-37.

Miyake, Y., Y. Sugiura and Y. Katsuragi (1956): Radioactive fallout at Asahikawa, Hokkaido in April, 1955. J. Met. Soc. Japan, Ser. II, 34, 226-230.

Nakaya, U. and T. Terada (1935): Simultaneous observations of the mass, falling velocity and form of individual snow crystals. Jour. Fac. Sci. Hokkaido Univ., 1, 191-200.

Nakaya, U. (1951): The formation of ice crystal. Compendium of Meteorology, pp. 207-220.

Sugawara, K. (1956): Geochemistry (in Japanese). Iwanami Press, $25 \mathrm{pp}$.

Takahashi, T. and C. Magono (1961): On crystarization of graupel and riming (in Japanese). Tenki, 8, 6-9.

Woodcock, A. H. (1953): Salt nuclei in marine air as a function of altitude and wind force. J. Met., 10, 362-371.

\section{雪の形と化学 成 分 \\ 高橋别 \\ (名古屋大学理学部水啠科学研究施設)}

雪の形別飞播集した試料飞ついて，その含有化学成分， $\mathrm{Cl}, \mathrm{Na}, \mathrm{NH}_{4}, \mathrm{SO}_{4}, \mathrm{Ca}, \mathrm{Mg}, \mathrm{NO}_{2}, \mathrm{Fe}, \mathrm{Si}$ を測定した。 雪は柱状結晶・雲粒つき六花・六花・放射状六花・霰など飞分類された。含有化学成分は, 雪の形別飞特徵的なあら われ方をすることがわかった。

（1）柱状結晶叶では， $\mathrm{Na}, \mathrm{Cl}, \mathrm{NH}_{4}$ の濃度は他の結晶形のものに比べ最も少ない。

(2) $\mathrm{NH}_{4}$ の蚛は六花飞最も多く含まれている。

(3) $\mathrm{Cl}$ と $\mathrm{Na}$ の濃度は, 霞で最大で, $\mathrm{Cl}$ と $\mathrm{Na}$ の比は, 海水中の $\mathrm{Cl}$ と $\mathrm{Na}$ の比と非常ととている。 